\title{
INFLUENCE OF TEMPERATURE ON THE FORMATION OF ALTERED LAYER DURING SILICON ETCHING IN $\mathrm{CF}_{2} \mathrm{Cl}_{2}$ PLASMA
}

\author{
R. Knizikevičius and A. Grigonis \\ Department of Physics, Kaunas University of Technology, K. Donelaičio 73, LT-44029 Kaunas, Lithuania \\ E-mail: Rimantas.Knizikevicius@ktu.lt
}

Received 5 December 2003

\begin{abstract}
Reactive ion etching of silicon in $\mathrm{CF}_{2} \mathrm{Cl}_{2}$ plasma is considered. During the experiment, silicon substrates are etched in $\mathrm{CF}_{2} \mathrm{Cl}_{2}$ plasma at temperatures of 320 and $390 \mathrm{~K}$. Thickness of formed altered layers is measured using an X-ray photoelectron spectrometer. The thickness of the altered layer decreases with the increase in temperature. Extrapolation of experimentally measured concentrations of $\mathrm{Si}$ atoms in the altered layer is used to determine processes that influence the decrease of the thickness of the altered layer at a higher temperature. It is determined that the thickness of the altered layer decreases with the increase in temperature due to slowdown of the chemical reaction of $\mathrm{CF}_{2}$ radicals with $\mathrm{Si}$ atoms and intensified desorption of formed $\mathrm{SiF}_{4}$ molecules.
\end{abstract}

Keywords: $\mathrm{CF}_{2} \mathrm{Cl}_{2}$ plasma, silicon, reactive ion etching, altered layer

PACS: 52.77.Bn, 82.35.Gh, 82.65.+r

\section{Introduction}

Isolation technology using silicon grooves is employed in high-speed integrated circuits. Important steps in a groove isolation process are: (i) reactive ion etching (RIE) of narrow and deep grooves in silicon, (ii) removal of the etching mask and cleaning of the grooves, (iii) refilling with dielectric materials, and (iv) planarization of the surface. The task of etching the grooves consists of finding an etch process with not only high anisotropy and high selectivity to the mask but also with high silicon etching rates and good compatibility with the other steps in the groove isolation process [1].

$\mathrm{CF}_{2} \mathrm{Cl}_{2}, \mathrm{Cl}_{2}$ molecules have high polarization as compared to $\mathrm{CF}_{x}(x \leq 2)$ [2], and atomization energy of $\mathrm{C}-\mathrm{Cl}$ species is much lower than $\mathrm{C}-\mathrm{F}$ [3], as a result, the concentrations of $\mathrm{CF}_{2}$ and $\mathrm{Cl}$ are increased in the bottom of a groove. $\mathrm{CF}_{2}$ and $\mathrm{CF}$ radicals produce a polymeric layer on the surface, and $\mathrm{SiCl}_{2}$ due to a high desorption activation energy [4] decreases the etching rate. The polymeric layer formed on the sidewalls becomes charged with the increase of groove depth, distorts trajectories of ions, and decreases the ion current density $[5,6]$. This effect is especially pronounced in narrow grooves [7]. When molecules and radicals arrive at such a narrow groove they are polarized and, during the interaction with the surface, de- compose into chemically active fragments that significantly change the rates of etching and polymerization reactions. These processes increase the etching anisotropy in shallow grooves and suppress etching in deep grooves.

The deposition rate decreases with the increase of the substrate temperature, and it is proportional to the volume of adsorbed particles. Less bondings of $\mathrm{C}$ atoms with $\mathrm{F}$ atoms exist in polymers deposited on a high-temperature substrate, in a low-pressure plasma, and at a high discharge power density [8]. $\mathrm{CF}_{2}$ radicals are a build-up material for polymeric layer during RIE of silicon in $\mathrm{CF}_{2} \mathrm{Cl}_{2}$ plasma.

In this work, one-dimensional RIE of silicon in $\mathrm{CF}_{2} \mathrm{Cl}_{2}$ plasma at different temperatures is investigated. The structures of the polymeric layer and the near-surface region are determined. Thickness of formed altered layers is measured using an X-ray photoelectron spectrometer. It is determined that the thickness of the altered layer decreases with the increase in temperature.

\section{Experimental}

The single-crystal silicon substrates (111) are etched in $\mathrm{CF}_{2} \mathrm{Cl}_{2}$ plasma. Prior to the etching silicon substrates were cleaned in a buffered HF solution. Alu- 
minum masks of $100 \mathrm{~nm}$ thickness were deposited by electron beam evaporation. The etching process is performed in the asymmetric diode system PK 2420 RIE. The frequency of discharge is $13.56 \mathrm{MHz}$, the flow rate of $\mathrm{CF}_{2} \mathrm{Cl}_{2}$ gas is $24 \mathrm{sccm}$, the discharge power density is $0.9 \mathrm{~W} / \mathrm{cm}^{2}$, the pressure is $26.7 \mathrm{~Pa}$, the energy of incident ions is $400 \mathrm{eV}$, the temperature is $290-390 \mathrm{~K}$, the etchable surface area is $25 \mathrm{~mm}^{2}$, and the etching time is $10 \mathrm{~min}$. The temperature of substrates is varied with an electrical heater. After etching the substrates are left for 20-40 $\mathrm{min}$ in the reactor to reach steadystate conditions and transferred through the air into the measurement chamber. The etching rate is measured using a scanning electron microscope JSM-25S. The composition of the near-surface layer is analysed using an X-ray photoelectron spectrometer 800 Kratos Analytical XPS.

\section{Model}

The RIE of the silicon substrate in $\mathrm{CF}_{2} \mathrm{Cl}_{2}$ plasma is simulated. The main products of dissociation of $\mathrm{CF}_{2} \mathrm{Cl}_{2}$ molecules are $\mathrm{CF}_{2} \mathrm{Cl}, \mathrm{CF}_{2}$ radicals, and $\mathrm{Cl}$ atoms [9]. In order to reduce the number of frequency probabilities that are freely chosen, only $\mathrm{CF}_{2}$ radicals are considered. $\mathrm{CF}_{2}$ radicals present in the plasma adsorb on the substrate surface:

$$
\mathrm{CF}_{2}(\mathrm{~g}) \rightarrow \mathrm{CF}_{2} \text { (ads). }
$$

This process is characterized by frequency probability of adsorption $\alpha=\alpha_{0} N_{\mathrm{CF}_{2}}$, where $\alpha_{0}$ is the sticking coefficient and $\mathrm{N}_{\mathrm{CF}_{2}}$ is the concentration of $\mathrm{CF}_{2}$ radicals in the plasma. Adsorbed $\mathrm{CF}_{2}$ radicals are activated by ion bombardment:

$$
\mathrm{CF}_{2}(\mathrm{ads})+\mathrm{A}^{+} \rightarrow \mathrm{CF}_{2}^{*}(\mathrm{ads})+\mathrm{A}^{+} .
$$

This process is characterized by the frequency probability of activation

$$
G=\frac{g I_{0}}{C_{0}}
$$

where $g$ is the activation constant, $I_{0}$ is the ion flux, and $C_{0}$ is the concentration of surface atoms $\left(C_{0}=\right.$ $1.36 \cdot 10^{19} \mathrm{~m}^{-2}$ ). The activated $\mathrm{CF}_{2}$ radicals are more likely to chemisorb species reaching the surface from the plasma and to change the kinetics of silicon etching rate and the thickness of the altered layer. The main reactions taking place in the adsorbed layer are as follows:

$$
\begin{aligned}
& \mathrm{Si}+2 \mathrm{CF}_{2} \stackrel{\mathrm{CF}_{2}^{*}}{\longrightarrow} \mathrm{SiF}_{4}+2 \mathrm{C}, \\
& \mathrm{C}+\mathrm{CF}_{2} \stackrel{\stackrel{\mathrm{CF}_{2}^{*}}{\longrightarrow}}{\mathrm{C}}-\mathrm{CF}_{2}, \\
& \left(\mathrm{CF}_{x}\right)_{n}+\mathrm{CF}_{2} \stackrel{\mathrm{CF}_{2}^{*}}{\longrightarrow}\left(\mathrm{CF}_{x}\right)_{n}-\mathrm{CF}_{2} .
\end{aligned}
$$

These reactions are characterized by frequency probabilities of reactions $R_{1}=k_{1} N_{\mathrm{CF}_{2}}^{2}, R_{2}=k_{2} N_{\mathrm{CF}_{2}}$, and $R_{3}=k_{3} N_{\mathrm{CF}_{2}}$, respectively, where $k_{i}$ is the reaction rate constant of the $i$ th reaction. The activated $\mathrm{CF}_{2}$ radicals relax: $\mathrm{CF}_{2}^{*} \rightarrow \mathrm{CF}_{2}$. This process is characterized by the frequency probability of relaxation $R_{\mathrm{r}}=1 / \tau$, where $\tau$ is the mean relaxation time.

The removal of the adsorbed layer components is characterized by the frequency probability of removal $\omega_{i}$, which consists of frequency probabilities of desorption and sputtering

$$
\begin{aligned}
\omega_{i} & =\omega_{i, \mathrm{~d}}+\omega_{i, \mathrm{~s}} \\
& =\nu_{0} \exp \left(-\frac{E_{i, \mathrm{~d}}}{k T}\right)+\frac{Y_{i} I_{0}}{C_{0}},
\end{aligned}
$$

where $\nu_{0}$ is the frequency of oscillation of atoms in the solid, $E_{i, \mathrm{~d}}$ is the desorption activation energy of the $i$ th component, $k$ is the Boltzmann constant, $T$ is the temperature, and $Y_{i}$ is the sputtering yield of the $i$ th component. The removal of surface components is characterized by frequency probabilities of sputtering $\omega_{i, \mathrm{~s}}$. Let us assume that the temperature of the altered layer is equal to the substrate temperature in the bulk.

$\mathrm{C}$ atoms produced during reaction of $\mathrm{CF}_{2}$ radicals with $\mathrm{Si}$ atoms (the first reaction in Eq. (4)) stick on the surface. The sticking processes of $\mathrm{C}$ atoms on $\mathrm{Si}$ and $\mathrm{C}$ atoms present on the surface are characterized by the sticking coefficients $\kappa_{46}$ and $\kappa_{47}$, respectively. As the processes of deposition and removal take place simultaneously, the stochastic mixing between monolayers (ML) occurs. When $\mathrm{C}$ atom is adsorbed on the surface, an atom of the $k$ th monolayer is transferred into the $(k+1)$ th monolayer. In this way, an altered layer with an elemental composition different from the bulk composition is formed. Reaction $\mathrm{Si}+2 \mathrm{Cl} \rightarrow \mathrm{SiCl}_{2}$ increases the etching rate at an elevated temperature, however, it does not influence the thickness of the altered layer. The influence of reaction $\mathrm{Si}+4 \mathrm{~F} \rightarrow \mathrm{SiF}_{4}$ on the etching rate is negligible.

It follows that five components exist in the adsorbed layer: $\mathrm{SiF}_{4}, \mathrm{CF}_{2}, \mathrm{CF}_{2}^{*}, \mathrm{C},\left(\mathrm{CF}_{x}\right)_{n}$, with relative con- 
centrations $c_{1}=\left[\mathrm{SiF}_{4}\right] / C_{0}, c_{2}=\left[\mathrm{CF}_{2}\right] / C_{0}, c_{3}=$ $\left[\mathrm{CF}_{2}^{*}\right] / C_{0}, c_{4}=[\mathrm{C}] / C_{0}$, and $c_{5}=\left[\left(\mathrm{CF}_{x}\right)_{n}\right] / C_{0}$; two components exist in the near-surface region: $\mathrm{Si}$ and $\mathrm{C}$, with relative concentrations $c_{6}=[\mathrm{Si}] / C_{0}$ and $c_{7}=[\mathrm{C}] / C_{0}$. The relative concentrations of components in the near-surface region must fulfill the following condition: $c_{6}+c_{7}=1$. It was found that only a model including physical and chemical processes in the adsorbed layer describes the silicon etching process in $\mathrm{CF}_{2} \mathrm{Cl}_{2}$ plasma. The following system of equations includes rate expressions of different processes $[10,11]$ and describes the kinetics of component concentrations in the adsorbed layer and in the near-surface region:

$$
\begin{aligned}
\frac{\mathrm{d} c_{1}}{\mathrm{~d} t}= & R_{1} \beta c_{3}^{2} c_{6}-\omega_{1} c_{1}, \\
\frac{\mathrm{d} c_{2}}{\mathrm{~d} t}= & \alpha \beta-G c_{2}+R_{\mathrm{r}} c_{3}-\omega_{2} c_{2}, \\
\frac{\mathrm{d} c_{3}}{\mathrm{~d} t}= & G c_{2}-R_{\mathrm{r}} c_{3}-\omega_{3} c_{3}, \\
\frac{\mathrm{d} c_{4}}{\mathrm{~d} t}= & 2 R_{1} \beta c_{3}^{2} c_{6}-R_{2} \beta c_{3} c_{4} \\
& -\kappa_{46} c_{4} c_{6}^{(1)}-\kappa_{47} c_{4} c_{7}^{(1)}-\omega_{4} c_{4}, \\
\frac{\mathrm{d} c_{5}}{\mathrm{~d} t}= & R_{2} \beta c_{3} c_{4}-R_{3} \beta c_{3} c_{5}-\omega_{5} c_{5}, \\
\frac{\mathrm{d} c_{6}^{(1)}}{\mathrm{d} t}= & -\kappa_{46} c_{4} c_{6}^{(1)}+c_{6}^{(2)} \omega_{7} c_{7}^{(1)}, \\
\frac{\mathrm{d} c_{6}^{(k)}}{\mathrm{d} t}= & V_{\mathrm{A}}\left(c_{6}^{(k-1)}-c_{6}^{(k)}\right),
\end{aligned}
$$

where $\beta=1-\Theta$ is the fraction of the surface not covered with adsorbate, $\Theta=\sum_{i=1}^{5} c_{i}$ is the surface coverage, and $V_{\mathrm{A}}=\kappa_{46} c_{4} c_{6}^{(1)}-\kappa_{47} c_{4} c_{7}^{(1)}$ is the deposition rate. The etching rate is proportional to the difference of removal and deposition rates:

$$
V=h_{0}\left(V_{\mathrm{S}}-V_{\mathrm{A}}\right),
$$

where $h_{0}=2.72 \AA$ is the monolayer thickness and $V_{\mathrm{S}}=\omega_{1} c_{1}$ is the removal rate.

\section{Results and discussion}

During RIE of silicon in $\mathrm{CF}_{2} \mathrm{Cl}_{2}$ plasma due to the presence of halocarbon radicals, deposition takes

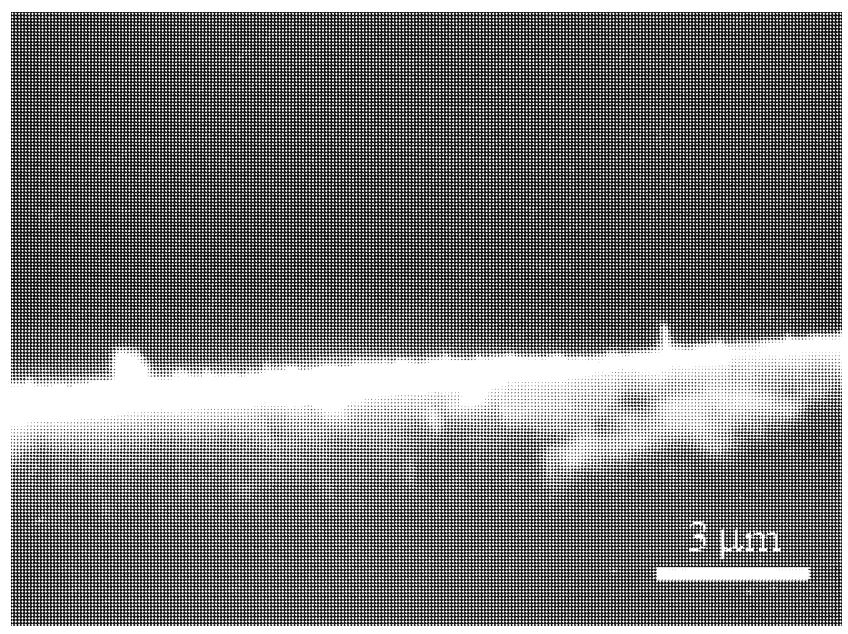

Fig. 1. The interface formed during silicon etching in $\mathrm{CF}_{2} \mathrm{Cl}_{2}$ plasma at the temperature $T=320 \mathrm{~K}$.

place. At a high energy of bombarding ions nonvolatile species are sputtered from the surface, however, at a low energy only the prevailing type of bonds changes. When concentrations of nonvolatile species with strong bonds approach steady-state values, the polymeric layer is formed. The presence of the polymeric layer on the surface reduces the etching rate of silicon. Composition of the polymeric layer depends on the energy of bombarding ions and etching time. The thickness of this layer is few nanometres.

The surface subjected to ion bombardment is in a thermodynamically unstable state, therefore, the formation of mechanical stresses and defects in a nearsurface region (up to $15 \mathrm{~nm}$ ) takes place [12]. In this region, due to the penetration of bombarding ions and diffusion, the interface with increased concentrations of $\mathrm{Si}-\mathrm{C}, \mathrm{Si}-\mathrm{F}$, and $\mathrm{Si}-\mathrm{Cl}$ species is formed (Fig. 1). $\mathrm{SiC}$ inclusions of different sizes exist under the polymeric layer in the near-surface region. These inclusions, defects, and mechanical stresses change electrical properties of a near-surface region. The thickness of the layer with altered electrical properties depends on the energy of bombarding ions and temperature, and extends up to $7 \mu \mathrm{m}$ [13]. On the other hand, with the increase of temperature in the reactor, intensive reemission of adsorbed particles takes place. The etchant products $\left(\mathrm{SiF}_{4}, \mathrm{SiCl}_{2}\right.$, etc. $)$ dissociate in the plasma and deposit on the surface. In this way, an $\alpha$-Si layer is formed.

The extrapolation of experimentally measured concentrations of $\mathrm{Si}$ atoms in the altered layer was used to determine processes that influence the decrease of thickness of the altered layer at a higher temperature. Experimentally measured and theoretically calculated 


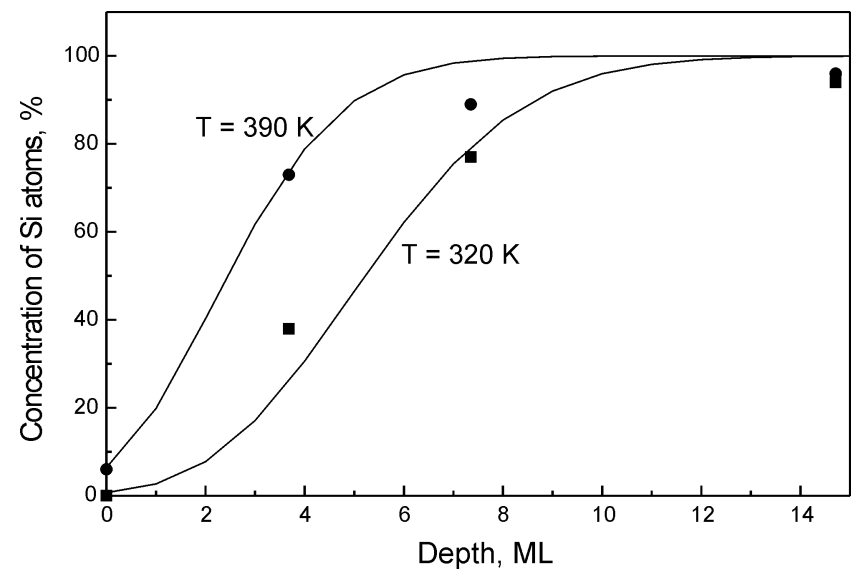

Fig. 2. Experimental (points) and theoretical (curves) concentrations of $\mathrm{Si}$ atoms in the altered layer at different temperatures.

using Eq. (6) concentrations of $\mathrm{Si}$ atoms in the altered layer are shown in Fig. 2. The following values of frequency probabilities were found by extrapolation:

$$
\begin{aligned}
\alpha(320,390 \mathrm{~K}) & =1.0 \mathrm{~s}^{-1}, \\
R_{1}(320 \mathrm{~K}) & =1.15 \cdot 10^{4} \mathrm{~s}^{-1}, \\
R_{1}(390 \mathrm{~K}) & =1.15 \cdot 10^{3} \mathrm{~s}^{-1}, \\
R_{2}(320,390 \mathrm{~K}) & =0.25 \mathrm{~s}^{-1}, \\
R_{3}(320,390 \mathrm{~K}) & =0.10 \mathrm{~s}^{-1}, \\
G(320,390 \mathrm{~K}) & =8.5 \cdot 10^{-5} \mathrm{~s}^{-1}, \\
R_{\mathrm{r}}(320,390 \mathrm{~K}) & =0 \mathrm{~s}^{-1}, \\
\omega_{1}(320 \mathrm{~K}) & =1.0 \cdot 10^{3} \mathrm{~s}^{-1}, \\
\omega_{1}(390 \mathrm{~K}) & =1.0 \cdot 10^{4} \mathrm{~s}^{-1}, \\
\omega_{2}(320,390 \mathrm{~K}) & =0.40 \mathrm{~s}^{-1}, \\
\omega_{3}(320,390 \mathrm{~K}) & =2.5 \cdot 10^{-4} \mathrm{~s}^{-1}, \\
\omega_{4}(320,390 \mathrm{~K}) & =100 \mathrm{~s}^{-1}, \\
\omega_{5}(320,390 \mathrm{~K}) & =4.0 \cdot 10^{-3} \mathrm{~s}^{-1}, \\
\omega_{7}(320,390 \mathrm{~K}) & =0 \mathrm{~s}^{-1}, \\
\kappa_{46}(320,390 \mathrm{~K}) & =4.0 \mathrm{~s}^{-1}, \\
\kappa_{47}(320,390 \mathrm{~K}) & =5.0 \mathrm{~s}^{-1},
\end{aligned}
$$

with $t=3600$ a.u. The theoretically calculated desorption activation energy of $\mathrm{SiF}_{4}$ molecules [14] was used to evaluate the frequency probabilities of desorption $\omega_{1}$ at different temperatures. The values of frequency probabilities of sticking $\kappa_{46}$ and $\kappa_{47}$ were found by extrapolation from the experimental data. The values of other frequency probabilities were found from the analysis of etching rate kinetics of silicon in $\mathrm{CF}_{2} \mathrm{Cl}_{2}$ plasma at different energies of bombarding ions [11]. The thickness of the altered layer decreases with the increase in temperature due to slowdown of the chemical reaction of $\mathrm{CF}_{2}$ radicals with $\mathrm{Si}$ atoms (the first reaction in Eq. (4)) and intensified desorption of formed $\mathrm{SiF}_{4}$ molecules. The decrease of the thickness of the altered layer at a higher temperature was observed in the experiment [8]. During the experiment the composition of polymeric layers formed in different halocarbon plasmas was analysed. XPS measurements showed that the concentrations of $\mathrm{C}-\mathrm{C}, \mathrm{C}-\mathrm{CF}_{x}$ species increased and that of $\mathrm{CF}_{x}$ radicals decreased with the increase in temperature.

\section{Conclusions}

1. During RIE of silicon in $\mathrm{CF}_{2} \mathrm{Cl}_{2}$ plasma a polymeric layer exists on the top of the substrate. $\mathrm{SiC}$ inclusions of different sizes exist under the polymeric layer in the near-surface region.

2. The thickness of the altered layer decreases with the increase in temperature due to slowered chemical reaction of $\mathrm{CF}_{2}$ radicals with $\mathrm{Si}$ atoms and intensified desorption of formed $\mathrm{SiF}_{4}$ molecules.

\section{References}

[1] G. Wöhl, M. Matthes, and A. Weisheit, Reactive ion etching of deep trenches in silicon with $\mathrm{CF}_{2} \mathrm{Cl}_{2}$ and $\mathrm{O}_{2}$, Vacuum 38(11), 1011-1014 (1988).

[2] N. Sakikawa, Y. Shishida, S. Miyazaki, and M. Hirose, In situ monitoring of silicon surfaces during reactive ion etching, Jpn. J. Appl. Phys. 37(4A), L409-L412 (1998).

[3] K. Tachibana, H. Kamisugi, and T. Kawasaki, Behavior of $\mathrm{F}$ atoms and $\mathrm{CF}_{2}$ radicals in fluorocarbon plasmas for $\mathrm{SiO}_{2} / \mathrm{Si}$ etching, Jpn. J. Appl. Phys. 38(7B), 4367-4370 (1999).

[4] R. Knizikevičius, Evaluation of desorption activation energy of $\mathrm{SiCl}_{2}$ molecules, Surf. Sci. 531(2), L347L350 (2003).

[5] G.S. Hwang and K. P. Giapis, The influence of mask thickness on charging damage during overetching, J. Appl. Phys. 82(2), 572-577 (1997).

[6] N. Fujiwara, T. Maruyama, and M. Yoneda, Profile control of poly-Si etching in electron cyclotron reso- 
nance plasma, Jpn. J. Appl. Phys. 34(4B), 2095-2100 (1995).

[7] G.S. Hwang and K. Giapis, Aspect-ratio-dependent charging in high-density plasmas, J. Appl. Phys. 82(2), 566-571 (1997).

[8] S. Arai, K. Tsujimoto, and S. Tachi, Deposition in dry-etching gas plasmas, Jpn. J. Appl. Phys. 31(6B), 2011-2019 (1992).

[9] W.W. Stoffels, E. Stoffels, M. Haverlag, G.M.W. Kroesen, and F.J. de Hoog, The chemistry of a $\mathrm{CCl}_{2} \mathrm{~F}_{2}$ radio frequency discharge, J. Vac. Sci. Technol. A 13(4), 2058-2066 (1995).

[10] M.A. Lieberman and A.J. Lichtenberg, Principles of Plasma Discharges and Materials Processing (Wiley, New York, 1994).
[11] A. Grigonis, R. Knizikevičius, Ž. Rutkūnienè, and M. Puceta, Kinetics of composition of polymeric layer during silicon etching in $\mathrm{CF}_{2} \mathrm{Cl}_{2}$ plasma, Appl. Surf. Sci. 199(1-4), 270-277 (2002).

[12] A. Rèza, G.-J. Babonas, Ž. Rutkūnienė, A. Grigonis, A. Galickas, V. Jasutis, and A. Kindurys, Optical response of ion-etched Si structures, Lithuanian J. Phys. 42(4), 285-290 (2002).

[13] V. Kunigèlis, A. Jucys, G. Bernotas, and A. Grigonis, Application of surface acoustic waves for investigation of plasma treated n-Si surface, Lithuanian J. Phys. 23(5), 88-91 (1983).

[14] R. Knizikevičius, Evaluation of desorption activation energy of $\mathrm{SiF}_{4}$ molecules, Vacuum 68(1), 29-30 (2002).

\title{
TEMPERATŪROS ITAKA PAKEISTO SLUOKSNIO SUSIDARYMUI, ĖSDINANT SILICI $\mathrm{CF}_{2} \mathrm{Cl}_{2}$ PLAZMOJE
}

\author{
R. Knizikevičius, A. Grigonis
}

Kauno technologijos universitetas, Kaunas, Lietuva

\section{Santrauka}

Išnagrinètas reaktyvus joninis silicio èsdinimas $\mathrm{CF}_{2} \mathrm{Cl}_{2}$ plazmoje. Eksperimento metu silicio bandiniai èsdinti $\mathrm{CF}_{2} \mathrm{Cl}_{2}$ plazmoje 320 ir $390 \mathrm{~K}$ temperatūroje. Susidariusių pakeistų sluoksnių storiai išmatuoti Röntgen'o fotoelektronu spektrometru. Pakeisto sluoksnio storis mažèja, didèjant temperatūrai. Eksperi- mentiškai išmatuotos $\mathrm{Si}$ atomų koncentracijos pakeistame sluoksnyje naudotos išaiškinti procesams, ittakojantiems pakeisto sluoksnio storio sumažèjimą aukštesnèje temperatūroje. Paaiškèjo, kad didejjant temperatūrai pakeisto sluoksnio storis mažèja dèl sulètejjusios $\mathrm{CF}_{2}$ radikalu reakcijos su $\mathrm{Si}$ atomais ir suintensyvejusios susidariusių $\mathrm{SiF}_{4}$ molekulių atvirkštinès gerties. 